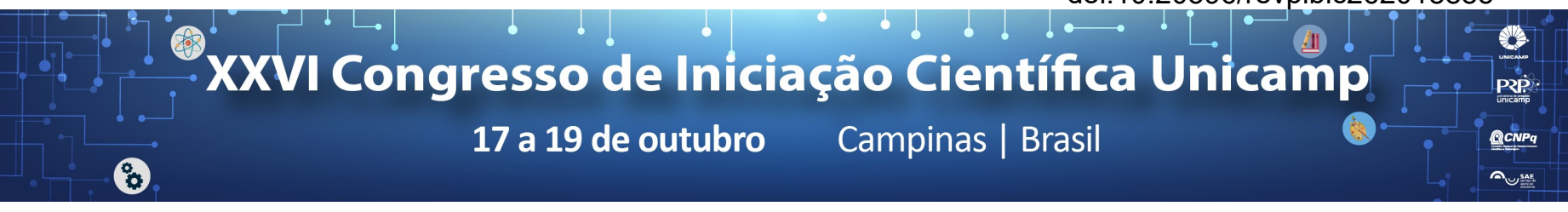

\title{
Design of poly-functionalized catalysts and additives for the Morita-Baylis-Hillman reaction
}

\section{Lucas G. dos Reis*, Lucas A. Zeoly, Fernando Coelho.}

\section{Resumo}

In this work we developed a new syntetic approach for the preparation of bi-functional catalysts derived from imidazole, without conformational constraints and having a center acting as Lewis base and other as Bronsted acid. These new catalysts were prepared in three steps, in overall yields ranging from $15 \%$ to up $48 \%$, using Morita-Baylis-Hillman adducts as building blocks.

Palavras-chave: Morita-Baylis-Hillman, Organocatalysis, Lewis bases.

\section{Introduction}

In the present, organocatalysis is a research area of great relevance, since it employs organic molecules to increase rate of organic processes, avoiding the use of metals. ${ }^{1}$ This project had as proposal planning, synthesizing and testing new bi-functional organocatalysts (2) in organic reactions, using Morita-Baylis-Hillman (MBH) adducts $^{2}$ as building blocks. THis work was based on previous results of our laboratory with catalyst 1 (BIA). ${ }^{3}$<smiles>OC1CCn2ccnc21</smiles><smiles>[R]C=C(CO)Cn1ccnc1</smiles>

Bi-functional analogs, without conformationa constraints (2)

Figure 1: BIA Molecule (1) compared with the planned new catalysts (2).

\section{Results and Discussion}

We began our work by preparing the $\mathrm{MBH}$ adducts. The results achieved were summarized in Table 1.

Table 1. Preparation of building blocks

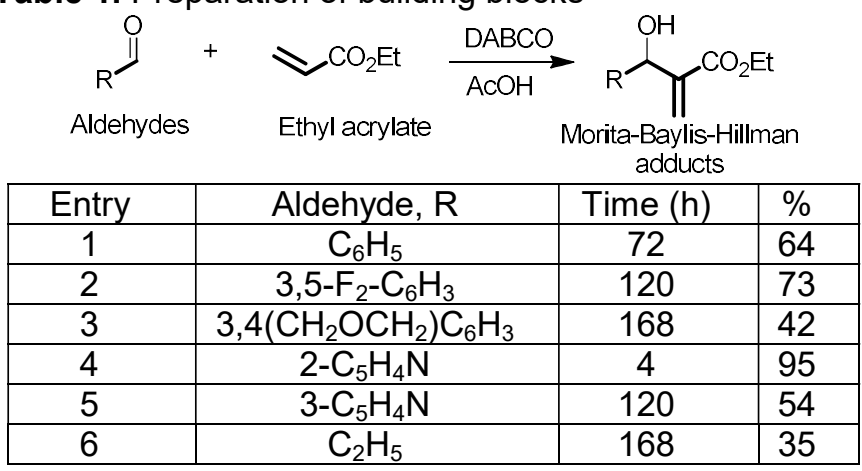

All adducts were successfully prepared (Table 1, entries 1-6) in good yields and reasonable reaction times. The spectral data $\left({ }^{1} \mathrm{H}-\mathrm{e}{ }^{13} \mathrm{C}\right.$ NMR) are compatible with the structures proposed for each one.

With the adducts in hands, we followed our synthetic planning. Thus, compounds 1-6 were submitted to the Michael addition conditions to provide the corresponding $\alpha$-substituted ethyl cinnamates. The results are summarized on Table $2{ }^{4}$

The conjugated additions afforded the $\alpha$-substituted cinnamic esters in good yields. The analysis of spectral data $\left({ }^{1} \mathrm{H}-\right.$ and $\left.{ }^{13} \mathrm{C}-\mathrm{NMR}\right)$ confirmed the proposed structures for each Michael adduct.
Tabela 2. Michael addition and ester reduction with DIBAL-H.

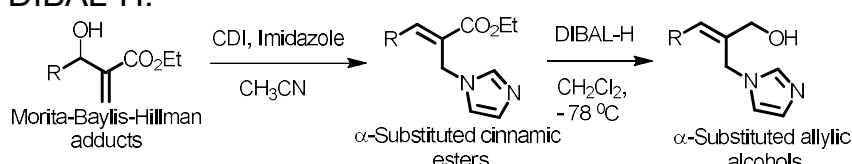

\begin{tabular}{|c|c|c|c|}
\hline \multicolumn{4}{c}{ Imidazole addition - cinnamic esters } \\
\hline Entry & $\mathrm{MBH}$ adducts & $\begin{array}{c}\text { Time } \\
\text { (h) }\end{array}$ & $\%$ \\
\hline 1 & $\mathrm{C}_{6} \mathrm{H}_{5}$ & 2 & 57 \\
\hline 2 & $3,5-\mathrm{F}_{2}-\mathrm{C}_{6} \mathrm{H}_{3}$ & 1 & 70 \\
\hline 3 & $3,4\left(\mathrm{CH}_{2} \mathrm{OCH}_{2}\right) \mathrm{C}_{6} \mathrm{H}_{3}$ & 1 & 56 \\
\hline 4 & $2-\mathrm{C}_{5} \mathrm{H}_{4} \mathrm{~N}$ & 2 & 85 \\
\hline 5 & $3-\mathrm{C}_{5} \mathrm{H}_{4} \mathrm{~N}$ & ${ }^{*}$ & ${ }^{*}$ \\
\hline 6 & $\mathrm{C}_{2} \mathrm{H}_{5}$ & ${ }^{*}$ & ${ }^{*}$ \\
\hline \multicolumn{4}{|c|}{ DIBAL-H reduction - allylic alcohols } \\
\hline Entry & $\mathrm{Cinnamic}$ esters & Time & $\%$ \\
\hline 7 & $3,5-\mathrm{F}_{2}-\mathrm{C}_{6} \mathrm{H}_{3}$ & 2 & 57 \\
\hline 8 & $3,4\left(\mathrm{CH}_{2} \mathrm{OCH}_{2}\right) \mathrm{C}_{6} \mathrm{H}_{3}$ & 2 & 62 \\
\hline 9 & $2-\mathrm{C}_{5} \mathrm{H}_{4} \mathrm{~N}$ & 2.5 & 60 \\
\hline
\end{tabular}

Following our synthetic planning, the dichloromethane solutions of cynammic esters were reduced by treatment with DIBAL-H at $-78{ }^{0} \mathrm{C}$ to afford th ecorresponding allylic alcohols in good yields. The results were summarized in Table 2 (second part).

At this stage of work, we were able to prepare the planned catalyst in three steps in overall yields ranginf to $15 \%$ to up $48 \%$. The efficiency of these new catalysts will be evaluated in the catalysis of some Morita-BaylisHillman reactions and aldolic condensations.

\section{Conclusions}

Based on an original synthetic planning we prepared some imidazolic allylic alcohols to be tested as bifunctional organocatalys in organic reactions. The main features of these new catalysts is its absence of conformational constraints and the presence of basic and acid centers.

\section{Acknowledgements}

Authors thank the Brazilian National Counsil for Scientific and Technological Development (CNPq) for the financial suport and fellowships.

${ }^{1}$ Dalko, P. I.; Moisen, L. Angew. Chem. Int. Ed. 2004, 43, 5138-5175; Coelho, F; Almeida, W. Quim. Nova 2000, 23, 98-101; ${ }^{3}$ Gomes, J. C.; Rodrigues, Jr., M. T.; Moyano, A.; Coelho, F. Eur. J. Org. Chem. 2012, 68616866; ${ }^{4}$ Rodrigues, M.; Santos, M.; Santos, H.; Coelho, F. Tetrahedron Lett. 2014, 55, 180-183. 